\title{
Medicolegal Case of Choriocarcinoma in a Developing Community
}

\author{
Wilson Onuigbo ${ }^{1 *}$ and Chukuedu Nwokolo ${ }^{2}$ \\ ${ }^{1}$ Department of Pathology, Medical Foundation \& Clinic, Nigeria \\ ${ }^{2}$ Department of Pathology, Medicine Specialist Hospital, Nigeria
}

Submission: December 08, 2017; Published: January 03, 2018

"Correspondence Address: Wilson Onuigbo, Department of Pathology, Medicine Specialist Hospital, Enugu 400001, Nigeria, Email: wilson.onuigbo@gmail.com

\begin{abstract}
Autopsy experience was described by two pathologists working at the Pathology Department of Queen Elizabeth Hospital, Barbados What came up concerned "undetected accidental deaths, suicides and homicides, undiagnosed contagious disease; and failure to recognize the appearance of new diseases in the environment." However, they included Cancer in their results. Incidentally, they included numerous coroner's autopsies, but did not specify. Accordingly, the present paper dwells on a Nigerian case with ordinary complaints that terminated in
\end{abstract} choriocarcinoma.

Keywords: Autopsy; Coroner; Benign presentation; Choriocarcinoma; Unused treatment

\section{Introduction}

A most informative report from Barbados concerned the autopsy experience of Prussia and Martin [1]. In particular, they mentioned "undetected accidental deaths, suicides and homicides, undiagnosed contagious disease; and failure to recognize the appearance of new diseases in the environment." Cancer was singled out for mention as well as coroner's autopsies. Therefore, this paper on personal autopsy work in Nigeria, is deemed worthy of documentation in that, a seemingly simple illness in a woman of the Igbo ethnic group [2], turned out to be fatal choriocarcinoma.

\section{Case Report}

$\mathrm{RE}$, a 30-year-old woman presented to the co-author (CN) with multiple complaints of earache, vomiting, pain in the neck and cough with hemoptysis. She was very ill looking. The temperature was $101 \mathrm{oF}$. In quick succession, there were enlarged mobile lymph nodes in both axillae. Three lumps appeared in the right breast. Also, hepatoaplenomegally appeared followed by neck stiffness and right sided hemiparesis. Unfortunately, management efforts such as lumbar puncture, culture and sensitivity tests were negative. There was no improvement and she expired.

Forensic autopsy was mandatory, although limited. The uterus was slightly enlarged and its cavity contained blood. There was a hemorrhagic mass near the fundus. The right ovary was enlarged and cystic. The liver appeared normal. Owing to the family's limitation of access, the diaphragm was cut into and the lungs were extracted. Both were loaded with multiple rounded nodules which were prominent in the right side. The skull was much affected. The left occipital lobe showed a $4.3 \mathrm{x}$ $3.6 \times 3.0 \mathrm{~cm}$ mass while a parietal nodule measured $1.5 \mathrm{~cm}$. On the right side, the occipital lobe exhibited 4 nodules up to 1.5 $\mathrm{cm}$ across with surrounding yellowish discoloration. Microscopy revealed that in the uterus, lymph nodes, breast, lung, liver and brain, choriocarcinoma was diagnostic.

\section{Discussion}

In this developing community, cancer in pregnancy was documented to be of renal origin [3]. It was also warned that one should be aware of the peculiarly colored vulvo-vaginal metastases [4]. In retrospect, the lymph nodes should have been biopsied. This is a practical method reviewed by Haskell and colleagues with special reference to unknown primary origins [5]. Therefore, it is a pity that by then, the treatment of choriocarcinoma had become possible [6]. Perhaps, this omission is explicable on the basis of the underdevelopment of the community!.

\section{References}

1. Prussia PR, Martin P (1987) Autopsy experience in Barbados. W I Med J 36(2): 1-7. 
2. Basden GT (1966) Niger Ibos. Cass, London, UK.

3. Onuigbo WIB, Ozoh JO, Onuigbo MAC, Umerah BC, Udeh FN (1992) Hypernephroma in pregnancy. Nig J Surg Sci 2: 29-31.

4. Onuigbo WIB (1978) Clinical awareness of vulvo-vaginal metastases in choricarcinoma. Nig Med J 8: 270-271.

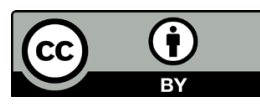

This work is licensed under Creative Commons Attribution 4.0 License

DOI: $10.19080 /$ CTOIJ.2018.08.555742
5. Haskell CM, Cochran AJ, Barsky SH, Steckel RJ (1988) Metastasis of unknown origin. Curr Prob Cancer 12(1): 5-58.

6. Hertz R, Bergenstal DM, Lipsett MB, Price EB, Hilbish TF (1958) Chemotherapy of chorio carcinoma and related trophoblastic tumors in women. J Am Med Assoc 168(7): 845-854.

\section{Your next submission with Juniper Publishers will reach you the below assets}

- Quality Editorial service

- Swift Peer Review

- Reprints availability

- E-prints Service

- Manuscript Podcast for convenient understanding

- Global attainment for your research

- Manuscript accessibility in different formats

( Pdf, E-pub, Full Text, Audio)

- Unceasing customer service

Track the below URL for one-step submission https://juniperpublishers.com/online-submission.php 